\title{
ANALISIS KESESUAIAN ANTARA KOMPONEN RPP BAHASA INDONESIA KELAS VII DI SMP NEGERI 14 LANGSA DAN KURIKULUM 2013
}

\author{
(Analysis of Conformity Between RPP Part Indonesian \\ Class VII In State 14 Langsa and Curriculum 2013)
}

\author{
Tara Astika Bangun \\ Universitas Negeri Medan \\ email: tyqa.chan@gmail.com
}

\begin{abstract}
ABSTRAK
Penelitian yang berjudul "Analisis Kesesuaian antara Komponene RPP Bahasa Indonesia Kelas VII di SMP Negeri 14 Langsa dan Kurikulum 2013" ini bertujuan mendeskripsikan kesesuaian antara RPP mata pelajaran bahasa Indonesia yang disusun oleh guru dan kurikulum 2013 di SMP Negeri 14 Langsa dan mendeskripsikan persentase kesesuaian komponen RPP mata pelajaran bahasa Indonesia tersebut. Sumber data penelitian ini adalah RPP yang dikembangkan oleh emapt guru bahasa Indonesia di SMPN 14 Langsa. Metode yang digunakan adalah metode deskriptif. Pengumpulan data dilakukan dengan teknik telaah dokumentasi dan pengolahan data dilakukan dengan teknik analisis kualitatif dan kuantitatif. Hasil analisis data yang diperoleh yaitu secara keseluruhan RPP yang disusun oleh empat responden banyak mengandung ketidaksesuaian dengan isi Permendikbud Nomor 81A tahun 2013 dalam komponen perumusan indikator pencapaian kompetensi; ketepatan dalam menggunakan kata kerja operasional; penyajian materi ajar dan organisasinya; kesesuaian antara sumber belajar dan karakter Kurikulum 2013; kejelasan dan kerincian skenario pembelajaran; kesesuaian teknik/metode pembelajaran; dan kelengkapan instrumen penilaian. Persentase kesesuaian komponen RPP mata pelajaran bahasa Indonesia yang disusun oleh empat guru di SMP Negeri 14 Langsa adalah 62,8\%.
\end{abstract}

Kata kunci: analisis, komponen, Rencana Pelaksanaan Pembelajaran, Kurikulum 2013

\begin{abstract}
The study, entitled "Analysis of Correspondence between Komponene RPP Indonesian Class VII in SMP Negeri 14 Langsa and Curriculum 2013" aims to describe the fit between RPP subjects Indonesian prepared by teachers and curriculum, 2013 in SMP Negeri 14 Langsa and describe the percentage of suitability component RPP the Indonesian subjects. The data source of this research is a lesson plan developed by four Indonesian teacher at SMPN 14 Langsa. The method used is descriptive method. The data collection was done by using the study of documentation and data processing was done by using qualitative and quantitative analysis. The results of the analysis of data obtained by the overall RPP compiled by four respondents contains a lot of mismatches with the content Permendikbud No. 81A of 2013 in the components of the formulation of indicators of achievement of competencies; accuracy in using the verb operations; presentation of teaching material and organization; correspondence between the learning resources and curriculum code 2013; the clarity and detail of learning scenarios; the suitability of the techniques / methods of learning; and completeness of assessment instruments. The percentage of subjects RPP component suitability Indonesian composed by four teachers at SMP Negeri 14 Langsa is $62.8 \%$.
\end{abstract}

Keywords: analysis, components, lesson plans, curriculum 2013 


\section{PENDAHULUAN}

Pendidikan merupakan hal terpenting bagi suatu negara agar dapat meningkatkan kualitas SDM-nya. Sariono (2013) mengutarakan bahwa kurikulum 2013 merupakan Kurikulum perubahan dari Kurikulum KTSP. Kurikulum 2013 memiliki tujuan yang tersurat di dalam Kompetensi Inti (KI) yang berjumlah empat. Konsep pembelajaran yang diterapkan di dalam Kurikulum 2013 ini adalah guru diharapkan bisa mengaitkan materi dengan situasi dunia nyata siswa sehari-hari (Contextual Learning) dan mengaitkan materi dengan ilmu yang lain (Interdisiplin Ilmu). Dalam hal ini, Rencana Pelaksanaan Pembelajaran (RPP) merupakan salah satu hal unsur terpenting dalam kurikulum dan PBM. Rencana Pelaksanaan Pembelajaran merupakan salah satu perangkat dalam sebuah Proses Belajar Mengajar yang harus disiapkan guru. Guru wajib memiliki kompetensi menyusun RPP sesuai dengan ketetapan pemerintah.

Kurikulum 2013 menggunakan pendekatan saintifik yaitu dengan mengedepankan 5 pembelajaran pokok yang dikenal dengan 5M, yaitu: Mengamati, Menanya, Mengumpulkan Informasi, Mengasosiasi dan Mengomunikasi. Kelima pengalaman belajar tersebut juga terdapat pada langkahlangkah kegiatan pembelajaran di RPP yang dibuat oleh guru. Rencana pelaksanaan pembelajaran merupakan rencana pembelajaran yang dikembangkan secara terperinci dari suatu materi pokok atau tema tertentu yang mengacu pada silabus. Berdasarkan pada Permendikbud Nomor 81A tahun 2013, isi dari RPP tersebut antara lain: (1) Data sekolah, mata pelajaran, kelas/semester; (2) materi pokok;
(3) alokasi waktu; (4) tujuan pembelajaran, KD dan indikator pencapaian kompetensi; (5) materi pembelajaran; metode pembelajaran, media, alat dan sumber belajar; (6) langkah-langkah kegiatan pembelajaran; dan (7) penilaian.

Indikator bahwa RPP yang dibuat oleh guru terlaksana adalah sesuai dengan Permendikbud Nomor 65 tahun 2013 tentang Standar Proses Pendidikan Dasar dan Menengah RPP dikembangkan dari silabus dalam rangka upaya untuk mencapai Kompetensi Dasar (KD). Guru memiliki beberapa tugas pokok yang harus dijalankan dalam pembelajaran salah satunya sebagai penyusun dari program rencana pelaksanaan pembelajaran. Sisi aspek konseptual menyebutkan bahwa, separuh responden guru belum mengetahui perbedaan antara Kurikulum 2013 dan Kurikulum 2006. Fakta tersebut merembet pada lemahnya perencanaan pelatihan dari pemerintah terkait. Wardhani (2013) menjelaskan bahwa hampir separuh guru mengaku masih tidak paham dengan teknis dalam menjabarkan materi Kurikulum 2013 ke dalam Rencana Pelaksanaan Pembelajaran. Subagia menambahkan bahwa pembelajaran dengan pendekatan ilmiah juga merupakan salah satu situasi pembelajaran yang diharapkan dalam Kurikulum 2013, tetapi fakta di lapangan menunjukkan bahwa baik guru sains maupun non-sains belum sepenuhnya menggunakan pendekatan ilmiah (scientific) dalam pelaksanaan pembelajaran.

Mengacu pada Permendikbud Nomor 81A tahun 2013, kecakapan guru dalam menyusun RPP merupakan hal yang tidak bisa ditawar lagi. Setiap guru mutlak menguasai langkah dan cara menyusun 
RPP. Berdasarkan data empiris di lapangan, peneliti sering menemukan kenyataan bahwa guru belum sepenuhnya memiliki kemampuan dalam menyusun RPP dalam kurikulum 2013 ini. Salah satu yang peneliti temukan pada saat mencermati RPP yang disusun oleh rekan guru yang lain di SMP Negeri 14 Langsa. Para guru tersebut belum mampu menyusun RPP sesuai dengan peraturan. Banyak guru yang hanya meng-copy paste RPP dari internet tanpa merevisinya lagi. Dengan adanya fenomena itu, peneliti merasa tertarik untuk meneliti RPP yang disusun oleh para guru di SMP Negeri 14 Langsa, khususnya pada RPP bahasa Indonesia. Melalui penelitian tersebut peneliti berharap mampu mengidentifikasi hal-hal yang kurang dikuasai para guru, khususnya guru Bahasa Indonesia dalam menyusun RPP sehingga hasil penelitian tersebut dapat memberi masukan kepada para guru atau pihak dinas pendidikan untuk membina para guru agar memiliki kemampuan dalam menyusun RPP sesuai dengan bidang keahliannya. Terlebih lagi, berdasarkan UU Sisdiknas tahun 2003 pendidikan di Indonesia harus mengandung pembinaan karakter. Hal tersebut berdampak, guru harus menyusun perangkat pembelajaran (salah satu di antaranya RPP) yang mengandung pembinaan karakter dan sesuai dengan kurikulum 2013. Berdasarkan latar belakang di atas maka penelitian ini mengkaji secara teoretik terhadap RPP yang disusun oleh guru Bahasa Indonesia di SMP Negeri 14 Langsa.

Berdasarkan latar belakang yang telah dikemukakan, masalah yang dapat dirumuskan dalam penelitian ini, yaitu (1) Bagaimana kesesuaian antara komponen RPP mata pelajaran bahasa Indonesia yang disusun oleh guru dan kurikulum 2013 di SMP Negeri 14 Langsa?
Bagaimana persentase kesesuaian komponen RPP mata pelajaran bahasa Indonesia yang disusun oleh guru di SMP Negeri 14 Langsa?

Tujuan penelitian ini, yaitu (1) mendeskripsikan kesesuaian antara RPP mata pelajaran bahasa Indonesia yang disusun oleh guru dan kurikulum 2013 di SMP Negeri 14 Langsa; dan (2) mendeskripsikan persentase kesesuaian komponen RPP mata pelajaran bahasa Indonesia yang disusun oleh guru di SMP Negeri 14 Langsa.

\section{LANDASAN TEORETIS}

\subsection{Pengertian RPP}

Mulyasa (2007:216) mengemukakah bahwa Rencana Pelaksanaan Pembelajaran (RPP) adalah rencana yang menggambarkan prosedur, dan pengorganisasian pembelajaran untuk mencapai satu kompetensi dasar yang ditetapkan. Dalam standar isi yang telah dijabarkan dalam silabus. Ruang lingkup rencana pembelajaran paling luass mencakup 1 (satu) kompetensi dasar yang terdiri atas 1(satu) atau beberapa indikator untuk 1 (satu) kali pertemuan atau lebih Proses mempersiapkan kegiatan-kegiatan secara sistematis yang akan dilakukan untuk mencapai tujuan. Menurut Peraturan Pemerintah (PP) No 19 tahun 2005 pasal 20 berbunyi bahwa perencanaan proses pembelajaran meliputi silabus dan rencana pelaksanaan pembelajaran yang memuat sekurang-kurangnya tujuan pembelajaran, materi pembelajaran, metode pembelajaran, sumber belajar dan penilaian hasil belajar. 


\subsection{Landasan Pengembangan RPP}

Landasan yang dijadikan acuan dalam mengembangkan RPP adalah:

(1) PP Nomor 19 tahun 2005 tentang SPN pasal 20 yang mengemukakan bahwa perencanaan proses pembelajaran meliputi Silabus dan Rencana Pelaksanaan Pembelajaran yang memuat sekurang-kurangnya tujuan pembelajaran, materi ajar, metode pengajaran, sumber belajar, dan penilaian hasil belajar;

(2) PERMENDIKNAS Nomor 41 Tahun 2007 tentang Standar Proses: (a) perencanaan proses pembelajaran meliputi silabus dan Rencana Pelaksanaan Pembelajaran (RPP) yang memuat identitas mata pelajaran, standar kompetensi (SK), kompetensi dasar (KD), indikator pencapaian kompetensi, tujuan pembelajaran, materi ajar, alokasi waktu, metode pembelajaran, kegiatan pembelajaran, penilaian hasil belajar, dan sumber belajar; (b) RPP dijabarkan dari silabus untuk mengarahkan kegiatan belajar peserta didik dalam upaya mencapai KD; (c) setiap guru pada satuan pendidikan berkewajiban menyusun RPP secara lengkap dan sistematis.

Sementara itu dalam kurikulum 2013, penyusunan RPP sudah diatur dalam Permendikbud Nomor 81A tahun 2013 yang berisi bahwa isi dari RPP tersebut antara lain:

(1) data sekolah, mata pelajaran, kelas/semester;

(2) materi pokok;

(3) alokasi waktu;

(4) tujuan pembelajaran, KD dan indikator pencapaian kompetensi;
(5) materi pembelajaran; metode pembelajaran, media, alat dan sumber belajar;

(6) langkah-langkah kegiatan pembelajaran; dan

(7) penilaian.

\subsection{Komponen RPP}

Wikanengsih, dkk. (2015:108) menjelaskan bahwa sebuah RPP harus memenuhi komponen sebagai berikut: (1) Identitas Mata Pelajaran: mengandung identitas yang jelas; (2) Standar Kompetensi: sesuai dengan kurikulum; (3) Kompetensi Dasar: sesuai dengan kurikulum; (4) Indikator Pencapaian Kompetensi: mengandung kata-kata yang operasional dan dapat diukur; (5) Tujuan Pembelajaran: mencakup tiga ranah belajar, kognitif, sikap, dan psikomotor; (6) Materi Ajar: Materi yang diberikan kepada peserta didik harus sesuai dengan tingkat perkembangannya. Pengorganisasian materi harus menarik agar mendorong siswa untuk belajar; (7) Alokasi Waktu: kesesuaian pengaturan waktu berdasarkan keperluan setiap langkah; (8) Metode Pembelajaran: ketepatan pemilihan metode; (9) Kegiatan Pembelajaran: memperlihatkan proses belajar yang mengaktifkan siswa dalam mencapai ketiga ranah belajar; (10) Penilaian Hasil Belajar: mengacu pada tujuan pembelajaran; dan (11) Sumber Belajar: menguakan berbagi macam sumber belajar.

\subsection{Rencana Pelaksanaan Pembelajaran dalam Kurikulum 2013}

Fadillah (2014: 182-187) menyatakan bahwa yang menjadi karakteristik pembelajaran Kurikulum 2013 adalah dalam teknik pembelajaran yang dikenal dengan pendekatan saintifik. Kegiatan atau langkah-langkah pembelajaran dalam 
rencana pelaksanaan pembelajaran Kurikulum 2013 terbagi menjadi tiga, yakni kegiatan pendahuluan, kegiatan inti, kegiatan akhir.

Kegiatan pendahuluan, yaitu

menyiapkan peserta didik secara psikis dan fisik untuk mengikuti proses pembelajaran; (2) mengajukan pertanyaan-pertanyaan tentang materi yang sudah dipelajari dan terkait dengan materi yang akan dipelajari.

(3) memberikan apersepsi dan mengantarkan peserta didik kepada suatu permasalahan atau tugas yang akan dilakukan untuk mempelajari suatu materi dan menjelaskan tujuan pembelajaran atau KD yang akan dicapai; (4) menyampaikan garis besar cakupan materi dan penjelasan tentang kegiatan yang akan dilakukan peserta didik untuk menyelesaikan permasalahan atau tugas. Kegiatan inti meliputi kegiatan mengamati, menanya, mengumpulkan, mengasosiasi atau mengolah informasi, dan mengomunikasikan hasil. Terakhir adalah kegiatan penutup. Dalam kegiatan penutup, guru bersama-sama dengan peserta didik membuat rangkuman atau simpulan pelajaran, melakukan penilaian atau refleksi terhadap kegiatan yang sudah dilaksanakan secara konsisten dan terprogram, memberikan umpan balik terhadap proses dan hasil pembelajaran, merencanakan kegiatan tindak lanjut dalam bentuk pembelajaran remedi, program pengayaan, layanan konseling dan/atau memberikan tugas baik tugas individual maupun kelompok sesuai dengan hasil belajar peserta didik, dan menyampaikan rencana pembelajaran pada pertemuan berikutnya.

\subsection{Hal-Hal yang Perlu Diperhatikan dalam Menyusun RPP}

Wikanengsih, dkk (2015:109) mengemukakah bahwa terdapat empat hal yang harus diperhatikan dalam menyusun RPP, yaitu sebagai berikut:

(1) RPP disusun untuk setiap KD yang dapat dilaksanakan dalam satu kali pertemuan atau lebih.

(2) Tujuan pembelajaran menggambarkan proses dan hasil belajar yang harus dicapai oleh peserta didik sesuai dengan kompetensi dasar.

(3) Tujuan pembelajaran dapat mencakupi sejumlah indikator, atau satu tujuan pembelajaran untuk beberapa indikator, yang penting tujuan pembelajaran harus mengacu pada pencapaian indikator.

(4) Kegiatan pembelajaran (langkahlangkah pembelajaran) dibuat setiap pertemuan, bila dalam satu RPP terdapat tiga kali pertemuan, maka dalam RPP tersebut terdapat tiga langkah pembelajaran. Bila terdapat lebih dari satu pertemuan untuk indikator yang sama, tidak perlu dibuatkan langkah kegiatan yang lengkap untuk setiap pertemuannya.

\section{METODE}

\subsection{Pendekatan dan Jenis Penelitian}

Penelitian ini menggunakan metode kombinasi/cmixed method, yaitu metode penelitian yang menggabungkan antara metode kualitatif dan metode kuantitatif. Creswell (2010:5) menjelaskan tentang metode campuran sebagai pendekatan penelitian yang mengombinasikan atau mengasosiasikan bentuk kualitatif dan bentuk kuantitatif. Pendekatan ini melibatkan asumsi-asumsi filosofis, aplikasi pendekatan kualitatif dan kuantitatif, dan pencampuran kedua pendekatan tersebut dalam satu penelitian. Pendekatan dalam bentuk kualitatif digunakan untuk mendeskripsikan 
kesesuaian antara komponen RPP dan kurikulum 2013, sedangkan pendekatan dalam bentuk kuantitatif digunakan untuk menghitung persentase kesesuaian komponen RPP mata pelajaran Bahasa Indonesia.

Sesuai dengan tujuan penelitian ini maka jenis pendekatan yang digunakan adalah deskriptif. Metode deskriptif memusatkan perhatiannya pada penemuan fakta-fakta (fact finding) sebagaimana keadaan sebenarnya (Nawawi dan Mimi, 2005:73). Penelitian deskriptif bertujuan untuk mendeskripsikan apa-apa yang saat ini berlaku. Di dalamnya terdapat upaya mendeskripsikan, mencatat, analisis, dan menginterpretasikan kondisi-kondisi yang sekarang ini terjadi atau ada (Mardalis, 2010:26). Penggunaan metode ini sesuai dengan penelitian yang dilakukan penulis, yaitu untuk mendeskripsikan kesesuaian antara komponen RPP mata pelajaran Bahasa Indonesia yang disusun oleh guru dan kurikulum 2013 di SMP Negeri 14 Langsa.

\subsection{Sumber Data, Populasi dan Sampel}

Subjek penelitian adalah guru mata pelajaran bahasa Indonesia kelas VII SMPN 14 Langsa yang berjumlah empat orang. Sumber data penelitian ini adalah RPP yang dikembangkan oleh emapt guru bahasa Indonesia di SMPN 14 Langsa. Populasi dalam penelitian ini adalah RPP mata pelajaran Bahasa Indonesia kelas VII semester satu yang disusun oleh guru di SMP Negeri 14 Langsa. Berdasarkan Standar Kompetensi di silabus, Kompetensi Dasar di kelas VII semester satu berjumlah 17, sehingga RPP yang disusun oleh guruguru yang bersangkutan juga berjumlah 17 RPP. Sampel yang digunakan sebanyak $25 \%$ dari jumlah populasi, yaitu 4 RPP bahasa Indonesia yang ditulis oleh empat guru bahasa Indonesia yang berbeda. Pengambilan sampel dilakukan secara acak dari setiap RPP kelas VII semester satu yang ditulis oleh setiap guru bahasa Indonesia tersebut.

\subsection{Teknik Pengumpulan Data}

Teknik pengumpulan data yang digunakan dalam penelitian ini adalah teknik telaah dokumentasi. Metode dokumentasi adalah kegiatan mengumpulkan data dengan mempelajari dokumen tertulis yang diperlukan (Parwanto, 2006:113). Dokumen yang digunakan berupa RPP bahasa Indonesia kelas VII semester satu yang disusun oleh guru bahasa Indonesia di SMP Negeri 14 Langsa. Penggunaan teknik ini dimaksudkan untuk mengetahui keadaan yang sebenarnya terhadap sesuatu yang didokumentasikan (Nasution, 2003:4).

\subsection{Teknik Penganalisisan Data}

Sesuai dengan metode yang digunakan, penganalisisan atau pengolahan data penelitian ini menggunakan teknik analisis campuran, yaitu kualitatif dan kuantitatif. Berdasarkan teknik analisis kualitatif, langkah-langkah yang ditempuh dalam penganalisisan data penelitian ini adalah sebagai berikut:

(1) mengidentifikasi dokumen RPP;

(2) menganalisis isi RPP;

(3) memverifikasi kesesuaian komponen RPP untuk dibuat simpulan.

Selanjutnya, digunakan teknik analisis kuantitatif untuk menentukan persentase kesesuaian komponen RPP mata pelajaran bahasa Indonesia dengan menggunakan rumus berikut.

$\mathrm{P}=\frac{\mathrm{f}}{\mathrm{N}} \times 100 \%$

Keterangan:

$\mathrm{P}=$ angka persentase 
$\mathrm{f}=$ frekuensi yang dihitung persentasenya

$\mathrm{N}=$ jumlah frekuensi yang dijadikan data 100\% = nilai tetap (Sudijono, 2009:43)

\section{HASIL DAN PEMBAHASAN}

\subsection{Analisis dan Deskripsi Data Penelitian}

Berikut ini adalah kesesuaian antara komponen RPP yang disusun oleh empat guru Bahasa Indonesia dengan kurikulum 2013 di SMP Negeri 14 Langsa. Deskripsi kesesuaian tersebut terangkum dalam hasil analisis yang terdapat pada tabel di bawah ini.

\section{Tabel 4.1 Data RPP I}

\begin{tabular}{|c|c|c|}
\hline No & $\begin{array}{c}\text { Aspek yang } \\
\text { Dianalisis }\end{array}$ & Hasil Analisis \\
\hline 1. & $\begin{array}{l}\text { Kelengkapan } \\
\text { Identitas Mata } \\
\text { Pelajaran }\end{array}$ & $\begin{array}{l}\text { Identitas mata } \\
\text { pelajaran ditulis } \\
\text { dengan lengkap } \\
\text { disertai dengan data } \\
\text { sekolah, } \\
\text { kelas/semester, } \\
\text { topik, subtema, dan } \\
\text { alokasi waktu. }\end{array}$ \\
\hline 2. & $\begin{array}{l}\text { Indikator } \\
\text { a) kesesuaian } \\
\text { dengan KI } \\
\text { b) kesesuaian } \\
\text { dengan KD } \\
\text { c) kesesuaian } \\
\text { dengan kata } \\
\text { kerja } \\
\text { operasional }\end{array}$ & $\begin{array}{l}\text { a) Indikator sesuai } \\
\text { dengan KI. } \\
\text { b) Terdapat satu } \\
\text { indikator yang } \\
\text { tidak sesuai } \\
\text { dengan KD. } \\
\text { c) Terdapat satu } \\
\text { indikator yang } \\
\text { tidak sesuai } \\
\text { dengan kata kerja } \\
\text { operasional. }\end{array}$ \\
\hline
\end{tabular}

\begin{tabular}{|c|c|c|}
\hline 3. & $\begin{array}{l}\text { Tujuan } \\
\text { Pembelajaran } \\
\text { a) kesesuaian } \\
\text { dengan KI } \\
\text { b) kesesuaian } \\
\text { dengan KD } \\
\text { c) kesesuaian } \\
\text { dengan kata } \\
\text { kerja } \\
\text { operasional } \\
\text { d) kejelasan } \\
\text { perumusan } \\
\text { tujuan } \\
\text { pembelajaran } \\
\text { (tidak } \\
\text { menimbulkan } \\
\text { penafsiran } \\
\text { ganda dan } \\
\text { mengandung } \\
\text { perilaku hasil } \\
\text { belajar) }\end{array}$ & $\begin{array}{l}\text { a) Tujuan } \\
\text { pembelajaran } \\
\text { tidak sesuai } \\
\text { dengan KI. } \\
\text { b) Tujuan } \\
\text { pembelajaran } \\
\text { sesuai dengan } \\
\text { KD. } \\
\text { c) Tujuan } \\
\text { pembelajaran } \\
\text { menggunakan } \\
\text { kata kerja } \\
\text { operasional yang } \\
\text { sesuai. } \\
\text { d) Rumusan tujuan } \\
\text { pembelajaran } \\
\text { sangat jelas (tidak } \\
\text { menimbulkan } \\
\text { makna ganda). }\end{array}$ \\
\hline 4. & $\begin{array}{l}\text { Materi Ajar } \\
\text { a) pemilihan } \\
\text { materi ajar } \\
\text { (sesuai } \\
\text { dengan tujuan } \\
\text { dan } \\
\text { karakteristik } \\
\text { peserta didik) } \\
\text { b) pengorganisasi } \\
\text { an materi ajar } \\
\text { (keruntutan, } \\
\text { sistematika } \\
\text { materi dan } \\
\text { kesesuaian } \\
\text { dengan alokasi } \\
\text { waktu) }\end{array}$ & $\begin{array}{l}\text { a) Materi } \\
\text { pembelajaran } \\
\text { hanya } \\
\text { mencantumkan } \\
\text { pokok-pokoknya, } \\
\text { materi ajar sesuai } \\
\text { dengan tujuan } \\
\text { pembelajaran, } \\
\text { tetapi tidak } \\
\text { mencerminkan } \\
\text { karakteristik } \\
\text { siswa. } \\
\text { b) Pengorganisasian } \\
\text { materi ajar tidak } \\
\text { terlihat } \\
\text { keruntutannya, } \\
\text { begitu juga } \\
\text { sistematika dan } \\
\text { alokasi waktunya. }\end{array}$ \\
\hline
\end{tabular}




\begin{tabular}{|c|c|c|}
\hline 5. & $\begin{array}{l}\text { Sumber Belajar } \\
\text { a) kesesuaian } \\
\text { dengan KI } \\
\text { dan KD } \\
\text { b) sesuai dengan } \\
\text { pendekatan } \\
\text { scientifiic } \\
\text { c) kesesuaian } \\
\text { dengan } \\
\text { karakter } \\
\text { kurikulum } \\
2013\end{array}$ & $\begin{array}{l}\text { a) Sumber belajar } \\
\text { sesuai dengan KI } \\
\text { dan KD, tetapi } \\
\text { tidak ada variasi. } \\
\text { b) Sumber belajar } \\
\text { sesuai dengan } \\
\text { scientific, tetapi } \\
\text { tidak ada variasi. } \\
\text { c) Sumber belajar } \\
\text { sesuai dengan } \\
\text { kurikulum 2013, } \\
\text { tetapi tidak ada } \\
\text { variasi. } \\
\text { Sumber } \\
\text { pembelajaran } \\
\text { hanya } \\
\text { menggunakan } \\
\text { buku paket yang } \\
\text { tersedia } \\
\text { sekolah, tidak } \\
\text { dilengkapi } \\
\text { sumber sebagai } \\
\text { pelengkap (untuk } \\
\text { menambah/memp } \\
\text { erkaya } \\
\text { pengetahuan } \\
\text { siswa). }\end{array}$ \\
\hline 6. & $\begin{array}{l}\text { Media } \\
\text { Pembelajaran } \\
\text { a) sesuai dengan } \\
\text { KD } \\
\text { b) sesuai dengan } \\
\text { tujuan } \\
\text { pembelajaran } \\
\text { c) sesuai dengan } \\
\text { pendekatan } \\
\text { scientific }\end{array}$ & 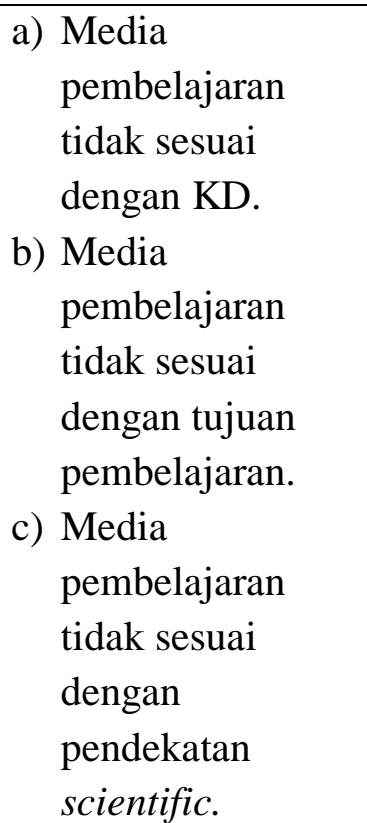 \\
\hline
\end{tabular}

\begin{tabular}{|c|c|c|}
\hline 7. & $\begin{array}{l}\text { Kegiatan } \\
\text { Pembelajaran } \\
\text { a) mencantumkan } \\
\text { kegiatan } \\
\text { pendahuluan } \\
\text { b) mencantumkan } \\
\text { kegiatan } \\
\text { scientific pada } \\
\text { kegiatan inti } \\
\text { c) mencatumkan } \\
\text { kegiatan } \\
\text { penutup } \\
\text { d) kejelasan dan } \\
\text { kerincian } \\
\text { skenario } \\
\text { pembelajaran } \\
\text { (setiap } \\
\text { langkah } \\
\text { tercermin } \\
\text { strategi/metode } \\
\text { dan alokasi } \\
\text { waktu pada } \\
\text { setiap tahap) }\end{array}$ & $\begin{array}{l}\text { a) Dalam kegiatan } \\
\text { pembelajaran, } \\
\text { dicantumkan } \\
\text { kegiatan } \\
\text { pendahuluan. } \\
\text { b) Dalam kegiatan } \\
\text { pembelajaran, } \\
\text { dicantumkan } \\
\text { kegiatan } \\
\text { scientific pada } \\
\text { kegiatan inti. } \\
\text { c) Dalam kegiatan } \\
\text { pembelajaran, } \\
\text { dicantumkan } \\
\text { kegiatan penutup. } \\
\text { d) Skenario } \\
\text { pembelajaran } \\
\text { terlihat cukup } \\
\text { jelas, tetapi tidak } \\
\text { disertai dengan } \\
\text { pengaturan } \\
\text { alokasi waktu } \\
\text { yang terencana } \\
\text { dengan baik. } \\
\text { Skenario } \\
\text { pembelajaran } \\
\text { tidak rinci, tidak } \\
\text { mencerminkan } \\
\text { metode/startegi } \\
\text { pembelajaran } \\
\text { yang digunakan, } \\
\text { meskipun } \\
\text { mengandung } \\
\text { tahap mengamati, } \\
\text { menanya, } \\
\text { mengeksplorasika } \\
\text { n, menalar, dan } \\
\text { mengomunikasik } \\
\text { an. }\end{array}$ \\
\hline 8. & $\begin{array}{l}\text { Penilaian } \\
\text { a) kesesuaian } \\
\text { dengan } \\
\text { indikator }\end{array}$ & $\begin{array}{l}\text { a) Instrumen } \\
\text { penilaian (kisi- } \\
\text { kisi) sesuai } \\
\text { dengan indikator }\end{array}$ \\
\hline
\end{tabular}




\begin{tabular}{|l|l|l|}
\hline \multicolumn{1}{|c|}{ pencapaian } & pencapaian \\
kompetensi & kompetensi \\
b) kelengkapan & b) Instrumen \\
instrumen & penilaian hanya \\
(soal, kunci, & berupa kisi-kisi \\
pedoman & soal, tidak \\
penskoran) & disertai pedoman \\
& penskoran \\
\hline
\end{tabular}

Berdasarkan hasil analisis tersebut, dapat diidentifikasikan ketidaksesuaian antara komponen RPP yang ditulis oleh responden dengan kurikulum 2013. Ketidaksesuaian tersebut yaitu:

(1) pada KD "memahami teks tanggapan deskriptif baik melalui lisan maupun tulisan", responden mencantumkan indikator "mampu menulis teks tanggapan deskriptif, sedangkan pada KD tersebut siswa masih dituntut untuk sekedar "memahami teks" dan bukan "menyusun teks";

(2) terdapat indikator yang tidak menggunakan kata kerja operasional, yakni pada indikator "Menghargai dan mensyukuri keberadaan bahasa Indonesia sebagai anugerah Tuhan Yang Maha Esa";

(3) tujuan pembelajaran yang tidak sesuai dengan KI, yakni pada tujuan "Peserta didik senantiasa menggunakan bahasa Indonesia dengan baik dan benar;

(4) materi ajar hanya mencantumkan pokok-pokoknya, seperti "Teks tanggapan deskriptif baik lisan maupun tulisan (video atau teks), Struktur isi teks tanggapan deskriptif, Ciri bahasa teks tanggapan deskriptif" dan tidak terlihat keruntutan dan sistematikanya;

(5) sumber belajar hanya menggunakan buku paket (buku guru dan buku siswa) yang tersedia di sekolah, tidak dilengkapi sumber sebagai pelengkap (untuk menambah/memperkaya pengetahuan siswa);

(6) media pembelajaran tidak sesuai dengan KD, tujuan pembelajaran, dan pendekatan scientific karena media yang digunakan adalah teks hasil observasi, sedangkan KD pada bagian ini adalah "memahami teks tanggapan deskriptif;

(7) skenario pembelajaran terlihat cukup jelas, tetapi tidak disertai dengan pengaturan alokasi waktu yang terencana dengan baik. Hal tersebut terlihat pada keseluruhan jumlah alokasi waktu yang tidak sesuai dengan jumlah pertemuan/alokasi waktu yang terdapat di bagian awal (identitas) RPP. Skenario pembelajaran tidak rinci, tidak mencerminkan metode/startegi pembelajaran yang digunakan, meskipun mengandung tahap mengamati, menanya, mengeksplorasikan, menalar, dan mengomunikasikan. Pada kegiatan pembelajaran, guru hanya menggunakan metode diskusi, sedangkan pada bagian metode pembelajaran guru mencantumkan metode demonstrasi;

(8) instrumen penilaian (kisi-kisi) sesuai dengan indikator pencapaian kompetensi, tetapi dilengkapi dengan pedoman penskoran.

Tabel 4.2 Data RPP II

\begin{tabular}{|c|c|c|}
\hline No. & Aspek yang & Hasil Analisis \\
\hline 1. & $\begin{array}{l}\text { Kelengkapan } \\
\text { Identitas Mata } \\
\text { Pelajaran }\end{array}$ & $\begin{array}{lr}\text { Identitas } & \text { mata } \\
\text { pelajaran } & \text { ditulis } \\
\text { dengan } & \text { lengkap } \\
\text { disertai } & \text { dengan } \\
\text { data } & \text { sekolah, } \\
\text { kelas/semester, }\end{array}$ \\
\hline
\end{tabular}




\begin{tabular}{|c|c|c|}
\hline & & $\begin{array}{l}\text { topik, subtema, } \\
\text { dan alokasi waktu. }\end{array}$ \\
\hline 2. & $\begin{array}{l}\text { Indikator } \\
\text { a) kesesuaian } \\
\text { dengan KI } \\
\text { b) kesesuaian } \\
\text { dengan KD } \\
\text { c) kesesuaian } \\
\text { dengan kata } \\
\text { kerja } \\
\text { operasional }\end{array}$ & $\begin{array}{l}\text { a) Indikator } \\
\text { sesuai dengan } \\
\text { KI. } \\
\text { b) Terdapat satu } \\
\text { indikator yang } \\
\text { tidak sesuai } \\
\text { dengan KD. } \\
\text { c) Indikator } \\
\text { sesuai dengan } \\
\text { kata kerja } \\
\text { operasional. }\end{array}$ \\
\hline 3. & $\begin{array}{l}\text { Tujuan } \\
\text { Pembelajaran } \\
\text { a) kesesuaian } \\
\text { dengan KI } \\
\text { b) kesesuaian } \\
\text { dengan KD } \\
\text { c) kesesuaian } \\
\text { dengan kata } \\
\text { kerja } \\
\text { operasional } \\
\text { d) kejelasan } \\
\text { perumusan } \\
\text { tujuan } \\
\text { pembelajaran } \\
\text { (tidak } \\
\text { menimbulkan } \\
\text { penafsiran } \\
\text { ganda dan } \\
\text { mengandung } \\
\text { perilaku } \\
\text { hasil } \\
\text { belajar) }\end{array}$ & $\begin{array}{l}\text { a) Tujuan } \\
\text { pembelajaran } \\
\text { sesuai dengan } \\
\text { KI. } \\
\text { b) Terdapat } \\
\text { tujuan tidak } \\
\text { pembelajaran } \\
\text { yang dengan } \\
\text { sesuai tidak } \\
\text { KD. } \\
\text { c) Terdapat } \\
\text { penggunaan } \\
\text { kata kerja } \\
\text { operasional } \\
\text { yang } \\
\text { sesuai. } \\
\text { d) Terdapat } \\
\text { rumusan tujuan } \\
\text { pembelajaran } \\
\text { yang tidak } \\
\text { jelas karena } \\
\text { tidak dapat } \\
\text { mengukur hasil } \\
\text { belajar siswa. }\end{array}$ \\
\hline
\end{tabular}

\begin{tabular}{|c|c|c|}
\hline 4. & $\begin{array}{l}\text { Materi Ajar } \\
\text { a) pemilihan } \\
\text { materi ajar } \\
\text { (sesuai } \\
\text { dengan } \\
\text { tujuan dan } \\
\text { karakteristik } \\
\text { peserta } \\
\text { didik) } \\
\text { b) pengorganis } \\
\text { asian materi } \\
\text { ajar } \\
\text { (keruntutan, } \\
\text { sistematika } \\
\text { materi dan } \\
\text { kesesuaian } \\
\text { dengan } \\
\text { alokasi } \\
\text { waktu) }\end{array}$ & $\begin{array}{l}\text { a) Pemilihan } \\
\text { materi ajar } \\
\text { sesuai dengan } \\
\text { tujuan dan } \\
\text { karakteristik } \\
\text { peserta didik. } \\
\text { b) Pengorganisasi } \\
\text { an materi ajar } \\
\text { runtut, tatapi } \\
\text { tidak sistematis } \\
\text { karena hanya } \\
\text { berupa pokok- } \\
\text { pokok materi. }\end{array}$ \\
\hline 5. & $\begin{array}{l}\text { Sumber } \\
\text { Belajar } \\
\text { a) kesesuaian } \\
\text { dengan KI } \\
\text { dan KD } \\
\text { b) sesuai } \\
\text { dengan } \\
\text { pendekatan } \\
\text { scientifiic } \\
\text { c) kesesuaian } \\
\text { dengan } \\
\text { karakter } \\
\text { kurikulum } \\
2013\end{array}$ & $\begin{array}{l}\text { a) Sumber belajar } \\
\text { sesuai dengan } \\
\text { KI dan KD, } \\
\text { tetapi tidak ada } \\
\text { variasi. } \\
\text { b) Sumber belajar } \\
\text { sesuai dengan } \\
\text { pendekatan } \\
\text { scientific, } \\
\text { tetapi tidak ada } \\
\text { variasi. } \\
\text { c) Sumber belajar } \\
\text { sesuai dengan } \\
\text { karakter } \\
\text { kurikulum } \\
\text { 2013, tatapi } \\
\text { tidak ada } \\
\text { variasi. }\end{array}$ \\
\hline 6. & $\begin{array}{l}\text { Media } \\
\text { Pembelajaran } \\
\text { a) sesuai } \\
\text { dengan KD } \\
\text { b) sesuai }\end{array}$ & $\begin{array}{l}\text { a) Media } \\
\text { pembelajaran } \\
\text { sesuai dengan } \\
\text { KD. } \\
\text { b) Media } \\
\text { pembelajaran }\end{array}$ \\
\hline
\end{tabular}




\begin{tabular}{|c|c|c|}
\hline & $\begin{array}{l}\text { dengan } \\
\text { tujuan } \\
\text { pembelajara } \\
\mathrm{n} \\
\text { c) sesuai } \\
\text { dengan } \\
\text { pendekatan } \\
\text { Scientifiec }\end{array}$ & $\begin{array}{l}\text { sesuai dengan } \\
\text { tujuan } \\
\text { pembelajaran. } \\
\text { c) Media } \\
\text { pembelajaran } \\
\text { sesuai dengan } \\
\text { dengan } \\
\text { pendekatan } \\
\text { scientifiec. }\end{array}$ \\
\hline 7. & $\begin{array}{l}\text { Kegiatan } \\
\text { Pembelajaran } \\
\text { a) mencantumk } \\
\text { an kegiatan } \\
\text { pendahuluan } \\
\text { b) mencantumk } \\
\text { an kegiatan } \\
\text { scientifiec } \\
\text { pada } \\
\text { kegiatan inti } \\
\text { c) mencatumka } \\
\text { n kegiatan } \\
\text { penutup } \\
\text { d) kejelasan } \\
\text { dan } \\
\text { kerincian } \\
\text { skenario } \\
\text { pembelajara } \\
\text { n (setiap } \\
\text { langkah } \\
\text { tercermin } \\
\text { strategi/met } \\
\text { ode dan } \\
\text { alokasi } \\
\text { waktu pada } \\
\text { setiap tahap) }\end{array}$ & $\begin{array}{l}\text { a) Dalam } \\
\text { kegiatan } \\
\text { pembelajaran, } \\
\text { dicantumkan } \\
\text { kegiatan } \\
\text { pendahuluan. } \\
\text { b) Dalam } \\
\text { kegiatan } \\
\text { pembelajaran, } \\
\text { dicantumkan } \\
\text { kegiatan } \\
\text { scientifiec pada } \\
\text { kegiatan inti. } \\
\text { c) Dalam } \\
\text { kegiatan } \\
\text { pembelajaran, } \\
\text { dicantumkan } \\
\text { kegiatan } \\
\text { penutup. } \\
\text { d) Kegiatan } \\
\text { pembelajaran } \\
\text { tidak jelas dan } \\
\text { tidak rinci serta } \\
\text { tidak tercermin } \\
\text { strategi/metode } \\
\text { inkuiri dan } \\
\text { discovery } \\
\text { learning yang } \\
\text { telah } \\
\text { ditetapkan, } \\
\text { perhitungan } \\
\text { alokasi waktu } \\
\text { tidak tepat. }\end{array}$ \\
\hline
\end{tabular}

\begin{tabular}{|c|c|c|}
\hline 8. & 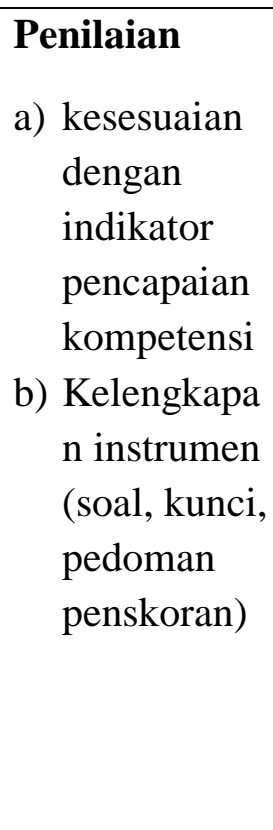 & $\begin{array}{l}\text { a) Instrumen } \\
\text { penilaian tidak } \\
\text { sesuai dengan } \\
\text { indikator } \\
\text { pencapaian } \\
\text { kompetensi. } \\
\text { b) Instrumen } \\
\text { penilaian tidak } \\
\text { lengkap, tidak } \\
\text { disertai kunci } \\
\text { jawaban soal } \\
\text { dan pedoman } \\
\text { penskoran } \\
\text { yang tidak } \\
\text { jelas. }\end{array}$ \\
\hline
\end{tabular}

Berdasarkan hasil analisis tersebut, dapat diidentifikasikan ketidaksesuaian antara komponen RPP yang ditulis oleh responden dengan kurikulum 2013. Ketidaksesuaian tersebut yaitu:

(1) pada bagian KI tidak diturunkan sebuah indikator;

(2) indikator tidak sesuai dengan $\mathrm{KD}$, yakni pada indikator "menemukan ide pokok tiap paragraf", sedangkan KDnya adalah "menangkap makna teks eksposisi";

(3) tujuan pembelajaran tidak sesuai dengan $\mathrm{KD}$, yakni pada tujuan "siswa mampu menentukan ide pokok teks eksposisi" dan terdapat tujuan pembelajaran yang tidak sesuai dengan indikator, seperti pada tujuan pembelajaran "siswa mampu menceritakan kembali isi teks eksposisi", tujuan pembelajaran juga tidak ditulis secara runtut. Pada tujuan pembelajaran, responden terlebih dahulu menentukan tujuan "siswa mampu menentukan ide pokok" kemudian tujuan selanjutnya "siswa mampu menentukan ciri-ciri dan struktur teks eksposisi, seharusnya 
terlebih dahulu siswa memahami ciri dan struktur teks tersebut sebelum menentukan ide pokok teks;

(4) terdapat penggunaan kata kerja operasional yang tidak sesuai dengan tujuan pembelajaran, yakni pada kata kerja "memahami" dalam tujuan pembelajaran "siswa dapat memahami makna teks eksposisi”. Kata kerja operasional tersebut tidak dapat diukur sehingga mengakibatkan tujuan pembelajaran tidak jelas;

(5) pengorganisasian materi ajar runtut, tatapi tidak sistematis karena hanya berupa pokok-pokok materi;

(6) sumber belajar hanya menggunakan buku paket (buku guru dan buku siswa) yang tersedia di sekolah, tidak dilengkapi sumber sebagai pelengkap (untuk menambah/memperkaya pengetahuan siswa);

(7) kegiatan pembelajaran tidak jelas dan tidak rinci serta tidak tercermin strategi/metode yang digunakan. Pada bagian metode pembelajaran, responden menuliskan metode inkuiri dan discovery learning, tetapi metode tersebut tidak tercermin dalam kegiatan pembelajaran. Media pembelajaran yang berupa kartu undian juga tidak digunakan dalam kegiatan pembelajaran. Selain itu, perhitungan alokasi waktu tidak tepat;

(8) Instrumen penilaian tidak sesuai dengan indikator pencapaian kompetensi. Hal tersebut terlihat pada instrumen penilaian "menemukan isi teks eksposisi" yang tidak ada dalam indikator, sedangkan untuk indikator "siswa mampu menceritakan kembali isi teks eksposisi" tidak tersedia dalam instrumen penilaian.
(9) Instrumen penilaian tidak lengkap karena tidak disertai kunci jawaban soal dan pedoman penskoran yang tidak jelas.

Tabel 4.3 Data RPP III

\begin{tabular}{|c|c|c|}
\hline No & $\begin{array}{c}\text { Aspek yang } \\
\text { Dianalisis }\end{array}$ & Hasil Analisis \\
\hline 1. & $\begin{array}{l}\text { Kelengkapan } \\
\text { Identitas Mata } \\
\text { Pelajaran }\end{array}$ & $\begin{array}{lr}\text { Identitas } & \text { mata } \\
\text { pelajaran } & \text { ditulis } \\
\text { dengan } & \text { lengkap } \\
\text { disertai } & \text { dengan } \\
\text { data } & \text { sekolah, } \\
\text { kelas/semester, } & \\
\text { topik, subtema, } & \text { dan alokasi waktu. }\end{array}$ \\
\hline 2. & $\begin{array}{l}\text { Indikator } \\
\text { a) kesesuaian } \\
\text { dengan KI } \\
\text { b) kesesuaian } \\
\text { dengan KD } \\
\text { c) kesesuaian } \\
\text { dengan kata } \\
\text { kerja } \\
\text { operasional }\end{array}$ & $\begin{array}{l}\text { a) Indikator } \\
\text { sesuai dengan } \\
\text { KI } \\
\text { b) Indikator } \\
\text { sesuai dengan } \\
\mathrm{KD} \\
\text { c) Indikator tidak } \\
\text { menggunakan } \\
\text { kata kerja } \\
\text { operasional } \\
\text { yang tepat. }\end{array}$ \\
\hline 3. & $\begin{array}{l}\text { Tujuan } \\
\text { Pembelajaran } \\
\text { a) kesesuaian } \\
\text { dengan KI } \\
\text { b) kesesuaian } \\
\text { dengan KD } \\
\text { c) kesesuaian } \\
\text { dengan kata } \\
\text { kerja } \\
\text { operasional } \\
\text { d) kejelasan } \\
\text { perumusan } \\
\text { tujuan } \\
\text { pembelajaran } \\
\text { (tidak } \\
\text { menimbulkan }\end{array}$ & $\begin{array}{l}\text { a) Tujuan } \\
\text { pembelajaran } \\
\text { sesuai dengan } \\
\text { KI. } \\
\text { b) Tujuan } \\
\text { pembelajaran } \\
\text { sesuai dengan } \\
\text { KD. } \\
\text { c) Tujuan } \\
\text { pembelajaran } \\
\text { tidak } \\
\text { menggunakan } \\
\text { kata kerja } \\
\text { operasional } \\
\text { yang tepat. } \\
\text { d) Terdapat }\end{array}$ \\
\hline
\end{tabular}




\begin{tabular}{|c|c|c|}
\hline & $\begin{array}{l}\text { penafsiran } \\
\text { ganda dan } \\
\text { mengandung } \\
\text { perilaku } \\
\text { hasil } \\
\text { belajar) }\end{array}$ & $\begin{array}{l}\text { rumusan tujuan } \\
\text { pembelajaran } \\
\text { yang tidak } \\
\text { jelas karena } \\
\text { tidak dapat } \\
\text { mengukur hasil } \\
\text { belajar siswa. }\end{array}$ \\
\hline 4. & $\begin{array}{l}\text { Materi Ajar } \\
\text { a) pemilihan } \\
\text { materi ajar } \\
\text { (sesuai } \\
\text { dengan } \\
\text { tujuan dan } \\
\text { karakteristik } \\
\text { peserta } \\
\text { didik) } \\
\text { b) pengorganis } \\
\text { asian materi } \\
\text { ajar } \\
\text { (keruntutan, } \\
\text { sistematika } \\
\text { materi dan } \\
\text { kesesuaian } \\
\text { dengan } \\
\text { alokasi } \\
\text { waktu) }\end{array}$ & $\begin{array}{l}\text { a) Materi ajar } \\
\text { sesuai dengan } \\
\text { tujuan } \\
\text { pembelajaran, } \\
\text { tetapi tidak } \\
\text { mencerminkan } \\
\text { karakteristik } \\
\text { peserta didik. } \\
\text { b) Pengorganisasi } \\
\text { an materi ajar } \\
\text { tidak terlihat } \\
\text { keruntutannya, } \\
\text { begitu juga } \\
\text { sistematika dan } \\
\text { alokasi } \\
\text { waktunya. }\end{array}$ \\
\hline 5. & $\begin{array}{l}\text { Sumber } \\
\text { Belajar } \\
\text { a) kesesuaian } \\
\text { dengan KI } \\
\text { dan KD } \\
\text { b) sesuai } \\
\text { dengan } \\
\text { pendekatan } \\
\text { scientifiic } \\
\text { c) kesesuaian } \\
\text { dengan } \\
\text { karakter } \\
\text { kurikulum }\end{array}$ & $\begin{array}{l}\text { a) Sumber belajar } \\
\text { sesuai dengan } \\
\text { KI dan KD, } \\
\text { tetapi tidak ada } \\
\text { variasi. } \\
\text { b) Sumber belajar } \\
\text { sesuai dengan } \\
\text { pendekatan } \\
\text { scientific, } \\
\text { tetapi tidak ada } \\
\text { variasi. } \\
\text { c) Sumber belajar } \\
\text { sesuai dengan } \\
\text { karakter }\end{array}$ \\
\hline
\end{tabular}

\begin{tabular}{|c|c|c|}
\hline & 2013 & $\begin{array}{l}\text { kurikulum } \\
\text { 2013, tatapi } \\
\text { tidak ada } \\
\text { variasi karena } \\
\text { tidak } \\
\text { mengandung } \\
\text { sumber bacaan } \\
\text { yang lengkap } \\
\text { untuk } \\
\text { memperkaya } \\
\text { pengetahuan } \\
\text { siswa. }\end{array}$ \\
\hline 6. & $\begin{array}{l}\text { Media } \\
\text { Pembelajaran } \\
\text { a) sesuai } \\
\text { dengan KD } \\
\text { b) sesuai } \\
\text { dengan } \\
\text { tujuan } \\
\text { pembelajaran } \\
\text { c) sesuai } \\
\text { dengan } \\
\text { pendekatan } \\
\text { Scientifiec }\end{array}$ & $\begin{array}{l}\text { Media } \\
\text { pembelajaran tidak } \\
\text { dicantumkan }\end{array}$ \\
\hline 7. & $\begin{array}{l}\text { Kegiatan } \\
\text { Pembelajaran } \\
\text { a) mencantumk } \\
\text { an kegiatan } \\
\text { pendahuluan } \\
\text { b) mencantumk } \\
\text { an kegiatan } \\
\text { scientifiec } \\
\text { pada } \\
\text { kegiatan inti } \\
\text { c) mencatumka } \\
\text { n kegiatan } \\
\text { penutup } \\
\text { d) kejelasan } \\
\text { dan } \\
\text { kerincian } \\
\text { skenario } \\
\text { pembelajara }\end{array}$ & $\begin{array}{l}\text { a) Dalam } \\
\text { kegiatan } \\
\text { pembelajaran, } \\
\text { dicantumkan } \\
\text { kegiatan } \\
\text { pendahuluan. } \\
\text { b) Dalam } \\
\text { kegiatan } \\
\text { pembelajaran, } \\
\text { dicantumkan } \\
\text { kegiatan } \\
\text { scientifiec pada } \\
\text { kegiatan inti. } \\
\text { c) Dalam } \\
\text { kegiatan } \\
\text { pembelajaran, } \\
\text { dicantumkan } \\
\text { kegiatan } \\
\text { penutup. }\end{array}$ \\
\hline
\end{tabular}




\begin{tabular}{|c|c|c|}
\hline & $\begin{array}{l}\text { n (setiap } \\
\text { langkah } \\
\text { tercermin } \\
\text { strategi/met } \\
\text { ode dan } \\
\text { alokasi } \\
\text { waktu pada } \\
\text { setiap tahap) }\end{array}$ & $\begin{array}{l}\text { d) Kegiatan } \\
\text { pembelajaran } \\
\text { tidak } \\
\text { mencerminkan } \\
\text { metode inkuiri } \\
\text { yang sudah } \\
\text { ditetapkan. }\end{array}$ \\
\hline 8. & $\begin{array}{l}\text { Penilaian } \\
\text { a) kesesuaian } \\
\text { dengan } \\
\text { indikator } \\
\text { pencapaian } \\
\text { kompetensi } \\
\text { b) kelengkapan } \\
\text { instrumen } \\
\text { (soal, kunci, } \\
\text { pedoman } \\
\text { penskoran) }\end{array}$ & $\begin{array}{l}\text { a) Instrumen } \\
\text { penilaian } \\
\text { sesuai dengan } \\
\text { indikator } \\
\text { pencapaian } \\
\text { kompetensi. } \\
\text { b) Pedoman } \\
\text { penskoran } \\
\text { tidak jelas. }\end{array}$ \\
\hline
\end{tabular}

Berdasarkan hasil analisis tersebut, dapat diidentifikasikan ketidaksesuaian antara komponen RPP yang ditulis oleh responden dengan kurikulum 2013. Ketidaksesuaian tersebut yaitu:

(1) indikator tidak menggunakan kata kerja operasional yang tepat karena menggunakan kata kerja "mengetahui" dan "memahami. Kata kerja tersebut tidak dapat mengukur hasil belajar siswa;

(2) terdapat penggunaan kata kerja operasional yang tidak sesuai dengan tujuan pembelajaran, yakni pada kata kerja "mengetahui" dan "memahami. Kata kerja operasional tersebut tidak dapat diukur sehingga mengakibatkan tujuan pembelajaran tidak jelas;

(3) materi ajar sesuai dengan tujuan pembelajaran, tetapi tidak mencerminkan karakteristik peserta didik karena hanya berisi pokok-pokok materi;

(4) pengorganisasian materi ajar tidak terlihat keruntutannya, begitu juga sistematika dan alokasi waktunya;

(5) sumber belajar hanya menggunakan buku paket (buku guru dan buku siswa) yang tersedia di sekolah, tidak dilengkapi sumber sebagai pelengkap (untuk menambah/memperkaya pengetahuan siswa);

(6) media pembelajaran tidak dicantumkan;

(7) kegiatan pembelajaran tidak mencerminkan strategi/metode inkuiri yang sudah ditetapkan, hanya metode diskusi yang terlihat;

(8) instrumen penilaian sesuai dengan indikator pencapaian kompetensi, tetapi pedoman penskoran tidak jelas karena terdapat kategori “jawaban sempurna dengan skor 5, jawaban kurang sempurna dengan skor 3, dan jawaban tidak sempurna dengan skor 1", kategori jawaban kurang sempurna dan jawaban tidak sempurna memiliki makna yang sama (jika kurang sempurna, tentunya tidak sempurna).

Tabel 4.4 Data RPP IV

\begin{tabular}{|c|c|c|}
\hline No. & $\begin{array}{c}\text { Aspek yang } \\
\text { Dianalisis }\end{array}$ & Hasil Analisis \\
\hline 1. & $\begin{array}{l}\text { Kelengkapan } \\
\text { Identitas Mata } \\
\text { Pelajaran }\end{array}$ & $\begin{array}{lr}\text { Identitas } & \text { mata } \\
\text { pelajaran } & \text { ditulis } \\
\text { dengan } & \text { lengkap } \\
\text { disertai } & \text { dengan } \\
\text { data } & \text { sekolah, } \\
\text { kelas/semester, } \\
\text { topik, subtema, } \\
\text { dan } \\
\text { waktu. }\end{array}$ \\
\hline
\end{tabular}




\begin{tabular}{|c|c|c|}
\hline 2. & $\begin{array}{l}\text { Indikator } \\
\text { a) kesesuaian } \\
\text { dengan KI } \\
\text { b) kesesuaian } \\
\text { dengan KD } \\
\text { c) kesesuaian } \\
\text { dengan kata } \\
\text { kerja } \\
\text { operasional }\end{array}$ & $\begin{array}{l}\text { a) Indikator } \\
\text { sesuai dengan } \\
\text { KI. } \\
\text { b) Indikator } \\
\text { sesuai dengan } \\
\mathrm{KD}, \quad \text { tetapi } \\
\text { masih kurang } \\
\text { lengkap. } \\
\text { c) Kata kerja } \\
\text { operasional } \\
\text { yang } \\
\text { digunakan } \\
\text { sudah sesuai. }\end{array}$ \\
\hline 3. & $\begin{array}{l}\text { Tujuan } \\
\text { Pembelajaran } \\
\text { a) kesesuaian } \\
\text { dengan KI } \\
\text { b) kesesuaian } \\
\text { dengan KD } \\
\text { c) kesesuaian } \\
\text { dengan kata } \\
\text { kerja } \\
\text { operasional } \\
\text { d) kejelasan } \\
\text { perumusan } \\
\text { tujuan } \\
\text { pembelajaran } \\
\text { (tidak } \\
\text { menimbulkan } \\
\text { penafsiran } \\
\text { ganda dan } \\
\text { mengandung } \\
\text { perilaku } \\
\text { hasil belajar) }\end{array}$ & 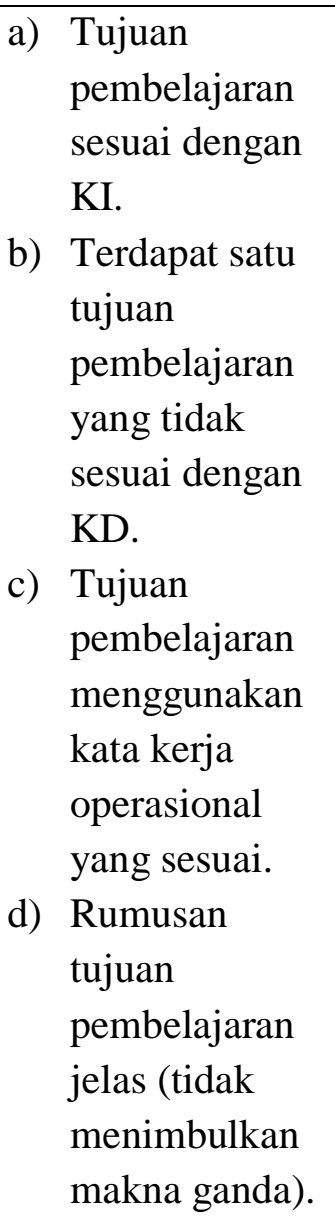 \\
\hline 4. & $\begin{array}{l}\text { Materi Ajar } \\
\text { a) pemilihan } \\
\text { materi ajar } \\
\text { (sesuai } \\
\text { dengan } \\
\text { tujuan dan } \\
\text { karakteristik } \\
\text { peserta didik) }\end{array}$ & 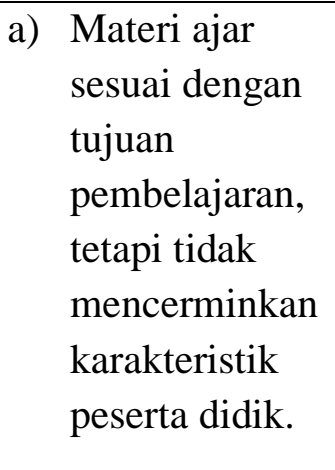 \\
\hline
\end{tabular}

\begin{tabular}{|c|c|c|}
\hline & $\begin{array}{l}\text { b) pengorganisa } \\
\text { sian materi } \\
\text { ajar } \\
\text { (keruntutan, } \\
\text { sistematika } \\
\text { materi dan } \\
\text { kesesuaian } \\
\text { dengan } \\
\text { alokasi } \\
\text { waktu) }\end{array}$ & $\begin{array}{l}\text { b) Pengorganisasi } \\
\text { an materi ajar } \\
\text { tidak terlihat } \\
\text { keruntutannya, } \\
\text { begitu juga } \\
\text { sistematika } \\
\text { dan alokasi } \\
\text { waktunya. }\end{array}$ \\
\hline 5. & $\begin{array}{l}\text { Sumber } \\
\text { Belajar } \\
\text { a) kesesuaian } \\
\text { dengan KI } \\
\text { dan KD } \\
\text { b) sesuai } \\
\text { dengan } \\
\text { pendekatan } \\
\text { scientifiic } \\
\text { c) kesesuaian } \\
\text { dengan } \\
\text { karakter } \\
\text { kurikulum } \\
2013\end{array}$ & $\begin{array}{l}\text { a) Sumber belajar } \\
\text { sesuai dengan } \\
\text { KI dan KD, } \\
\text { tetapi tidak } \\
\text { ada variasi. } \\
\text { b) Sumber belajar } \\
\text { sesuai dengan } \\
\text { pendekatan } \\
\text { scientific, } \\
\text { tetapi tidak } \\
\text { ada variasi. } \\
\text { Sumber belajar } \\
\text { sesuai dengan } \\
\text { karakter } \\
\text { kurikulum } \\
\text { 2013, tatapi } \\
\text { tidak ada } \\
\text { variasi karena } \\
\text { tidak } \\
\text { mengandung } \\
\text { sumber bacaan } \\
\text { yang lengkap } \\
\text { untuk } \\
\text { memperkaya } \\
\text { pengetahuan } \\
\text { siswa. }\end{array}$ \\
\hline
\end{tabular}




\begin{tabular}{|c|c|c|}
\hline 6. & $\begin{array}{l}\text { Media } \\
\text { Pembelajaran } \\
\text { a) sesuai } \\
\text { dengan KD } \\
\text { b) sesuai } \\
\text { dengan } \\
\text { tujuan } \\
\text { pembelajaran } \\
\text { c) sesuai } \\
\text { dengan } \\
\text { pendekatan } \\
\text { scientifiec }\end{array}$ & $\begin{array}{l}\text { a) Media } \\
\text { pembelajaran } \\
\text { tidak sesuai } \\
\text { dengan KD, } \\
\text { karena hanya } \\
\text { berupa teks } \\
\text { observasi, } \\
\text { tidak disertai } \\
\text { dengan media } \\
\text { lainnya. } \\
\text { b) Media } \\
\text { pembelajaran } \\
\text { tidak sesuai } \\
\text { dengan tujuan } \\
\text { pembelajaran, } \\
\text { karena hanya } \\
\text { berupa teks } \\
\text { observasi, } \\
\text { tidak disertai } \\
\text { dengan media } \\
\text { lainnya. } \\
\text { c) Media } \\
\text { pembelajaran } \\
\text { tidak sesuai } \\
\text { dengan } \\
\text { pendekatan } \\
\text { scientifiec. }\end{array}$ \\
\hline 7. & $\begin{array}{l}\text { Kegiatan } \\
\text { Pembelajaran } \\
\text { a) mencantumk } \\
\text { an kegiatan } \\
\text { pendahuluan } \\
\text { b) mencantumk } \\
\text { an kegiatan } \\
\text { scientifiec } \\
\text { pada } \\
\text { kegiatan inti } \\
\text { c) mencatumka } \\
\text { n kegiatan } \\
\text { penutup } \\
\text { d) kejelasan } \\
\text { dan } \\
\text { kerincian }\end{array}$ & $\begin{array}{l}\text { a) Dalam } \\
\text { kegiatan } \\
\text { pembelajaran, } \\
\text { dicantumkan } \\
\text { kegiatan } \\
\text { pendahuluan. } \\
\text { b) Dalam } \\
\text { kegiatan } \\
\text { pembelajaran, } \\
\text { dicantumkan } \\
\text { kegiatan } \\
\text { scientifiec } \\
\text { pada kegiatan } \\
\text { inti. } \\
\text { c) Dalam } \\
\text { kegiatan }\end{array}$ \\
\hline
\end{tabular}

\begin{tabular}{|c|c|c|}
\hline & $\begin{array}{l}\text { skenario } \\
\text { pembelajara } \\
\mathrm{n} \text { (setiap } \\
\text { langkah } \\
\text { tercermin } \\
\text { strategi/meto } \\
\text { de dan } \\
\text { alokasi } \\
\text { waktu pada } \\
\text { setiap tahap) }\end{array}$ & $\begin{array}{l}\text { pembelajaran, } \\
\text { dicantumkan } \\
\text { kegiatan } \\
\text { penutup. } \\
\text { d) Kegiatan } \\
\text { pembelajaran } \\
\text { tidak } \\
\text { mencerminkan } \\
\text { metode inkuiri } \\
\text { dan resitasi } \\
\text { yang sudah } \\
\text { ditetapkan. }\end{array}$ \\
\hline 8. & $\begin{array}{l}\text { Penilaian } \\
\text { a) kesesuaian } \\
\text { dengan } \\
\text { indikator } \\
\text { pencapaian } \\
\text { kompetensi } \\
\text { b) kelengkapan } \\
\text { instrumen } \\
\text { (soal, kunci, } \\
\text { pedoman } \\
\text { penskoran) }\end{array}$ & $\begin{array}{l}\text { a) Instrumen } \\
\text { penilaian ada } \\
\text { yang tidak } \\
\text { sesuai dengan } \\
\text { indikator } \\
\text { pencapaian } \\
\text { kompetensi. } \\
\text { b) Instrumen } \\
\text { penilaian tidak } \\
\text { dilengkapi } \\
\text { dengan kunci } \\
\text { jawaban dan } \\
\text { pedoman } \\
\text { penskoran } \\
\text { yang jelas. }\end{array}$ \\
\hline
\end{tabular}

Berdasarkan hasil analisis tersebut, dapat diidentifikasikan ketidaksesuaian antara komponen RPP yang ditulis oleh responden dengan kurikulum 2013. Ketidaksesuaian tersebut yaitu:

(1) indikator sesuai dengan $\mathrm{KD}$, tetapi masih kurang lengkap karena pada KD "meringkas teks observasi", responden hanya menurunkan indikator "Peserta didik mampu menyusun ringkasan teks observasi" dan "Peserta didik mampu menentukan intisari dari teks observasi”, seharusnya responden juga mencantumkan indikator "Peserta didik mampu menyusun kerangka ringkasan". 
4.2 Persentase Kesesuaian antara Komponen RPP dan Kurikulum 2013

Tabel 4.5 Persentase Kesesuaian Komponen RPP Mata Pelajaran Bahasa Indonesia Kelas VII Semester 1

\begin{tabular}{|c|c|c|c|c|}
\hline \multirow[t]{2}{*}{ Aspek } & \multicolumn{4}{|c|}{ RPP } \\
\hline & I & II & III & IV \\
\hline \multicolumn{5}{|l|}{ Identitas Mata Pelajaran } \\
\hline kelengkapan identitas mata pelajaran & 4 & 4 & 4 & 4 \\
\hline \multicolumn{5}{|l|}{ Indikator } \\
\hline a) kesesuaian dengan $\mathrm{KI}$ & 4 & 4 & 4 & 4 \\
\hline b) kesesuaian dengan $\mathrm{KD}$ & 3 & 3 & 4 & 2 \\
\hline c) kesesuaian kata kerja operasional & 3 & 4 & 0 & 4 \\
\hline \multicolumn{5}{|l|}{ Tujuan Pembelajaran } \\
\hline a) kesesuaian dengan $\mathrm{KI}$ & 1 & 4 & 4 & 4 \\
\hline b) kesesuaian dengan $\mathrm{KD}$ & 3 & 2 & 4 & 3 \\
\hline c) kesesuaian dengan kata kerja operasional & 4 & 2 & 0 & 4 \\
\hline \multicolumn{5}{|l|}{ Materi Ajar } \\
\hline a) kesesuaian dengan tujuan pembelajaran & 4 & 4 & 4 & 4 \\
\hline b) kesesuaian dengan kriteria peserta didik & 2 & 3 & 2 & 2 \\
\hline \multicolumn{5}{|l|}{ Sumber Belajar } \\
\hline a) kesesuaian dengan $\mathrm{KI}$ dan $\mathrm{KD}$ & 3 & 3 & 3 & 3 \\
\hline b) sesuai dengan pendekatan scientific & 3 & 3 & 3 & 3 \\
\hline c) kesesuaian dengan karakter Kurikulum 2013 & 2 & 2 & 2 & 2 \\
\hline \multicolumn{5}{|l|}{ Materi Pembelajaran } \\
\hline a) sesuai dengan $\mathrm{KD}$ & 0 & 4 & 0 & 0 \\
\hline b) sesuai dengan tujuan pembelajaran & 0 & 4 & 0 & 0 \\
\hline c) sesuai dengan pendekatan scientific & 1 & 4 & 0 & 0 \\
\hline \multicolumn{5}{|l|}{ Kegiatan Pembelajaran } \\
\hline a) mencantumkan kegiatan pendahuluan & 4 & 4 & 4 & 4 \\
\hline
\end{tabular}




\begin{tabular}{|l|c|c|c|c|}
\hline $\begin{array}{l}\text { b) mencantumkan kegiatan scientifiec pada } \\
\text { kegiatan inti }\end{array}$ & 4 & 4 & 4 & 4 \\
\hline c) mencatumkan kegiatan penutup & 4 & 4 & 4 & 4 \\
\hline Penilaian & 3 & 1 & 4 & 3 \\
\hline $\begin{array}{l}\text { a) kesesuaian dengan indikator pencapaian } \\
\text { kompetensi }\end{array}$ & 1 & 2 & 2 & 2 \\
\hline b) kesesuaian dengan penilaian autentik & $\mathbf{5 3}$ & $\mathbf{6 5}$ & $\mathbf{5 2}$ & $\mathbf{5 6}$ \\
\hline$\sum$ & & $\mathbf{6 2 , 8} \%$ & \\
\hline Persentase & & \multicolumn{5}{|c|}{} \\
\hline
\end{tabular}

Berdasarkan tabel 4.5 dapat diketahui bahwa perolehan hasil persentase kesesuaian antara komponen RPP kelas VII semester satu dan Kurikulum 2013 adalah 62,8\%. Hasil tersebut diperoleh berdasarkan skor hasil telaah RPP bahasa Indonesia yang disusun oleh empat guru SMP Negeri 5 Langsa. Skor yang diperoleh dari hasil telaah RPP adalah 53, 65, 52, dan 56.

\section{PENUTUP}

\subsection{Kesimpulan}

Berdasarkan analisis data dan perhitungan persentase kesesuaian antara komponen RPP dan Kurikulum 2013 dapat disimpulkan beberapa hal berikut.

(1) RPP yang disusun oleh empat responden banyak mengandung ketidaksesuaian dengan isi Permendikbud Nomor 81A tahun 2013 dalam komponen perumusan indikator pencapaian kompetensi; ketepatan dalam menggunakan kata kerja operasional; penyajian materi ajar dan organisasinya; kesesuaian antara sumber belajar dan karakter Kurikulum 2013; kejelasan dan kerincian skenario pembelajaran;

kesesuaian teknik/metode pembelajaran; dan kelengkapan instrumen penilaian.

(2) Persentase kesesuaian komponen RPP mata pelajaran bahasa Indonesia yang disusun oleh empat guru di SMP Negeri 5 Langsa adalah 62,8\%.

\subsection{Saran}

Sehubungan dengan penelitian ini dapat dikemukakan saran sebagai berikut:

(1) guru sebaiknya lebih memahami prinsip penyusunan RPP yang sesuai dengan Permendikbud;

(2) guru sebaiknya lebih aktif mengikuti kegiatan pelatihan-pelatihan;

(3) guru tidak hanya cukup memiliki kemampuan mengajar, tetapi juga harus memiliki kemampuan dalam membuat perencanaan KBM;

(4) perlu adanya penelitian serupa yang lebih spesifik yaitu dengan melakukan analisis RPP dan KBM yang dijalankan guru;

(5) perlu adanya diskusi dalam waktu tertentu agar antarguru memiliki pemahaman yang sama tentang kurikulum yang sedang berjalan; 
(6) perlu adanya intensitas yang lebih pendampingan. ditingkatkan dengan adanya

\section{DAFTAR PUSTAKA}

Creswell, J.W. 2010. Research Design: Pendekatan Kualitatif, Kuantitatif dan Mixed. Terjemahan. Yogyakarta: Pustaka Pelajar.

Depdiknas (2007). Permendiknas Nomor 41 Tahun 2007 tentang Standar Proses. Jakarta: Depdiknas.

Fadillah, M. 2014. Implementasi Kurikulum 2013 dalam Pembelajaran SD/MI/SMP/MTS, \& SMA/MA. Yogyakarta: Ar-Ruzz Media.

Mardalis. 2010. Metode Penelitian Suatu Pendekatan Proposal. Jakarta: Bumi Aksara.

Mulyasa, E. 2007. Kurikulum Tingkat Satuan Pendidikan. Bandung: PT. Remaja Rosdakarya.

Nasution, S. 2003. Metode Research. Jakarta: Bumi Raksasa.

Nawawi, H. Hadari dan Mimi Martini. 2005. Penelitian Terapan. Yogyakarta: Gadjah Mada Press.

Kemendikbud. 2013. Peraturan Menteri Pendidikan dan Kebudayaan Republik Indonesia Nomor 81A Tahun 2013 tentang Implementasi Kurikulum. Jakarta: Kemendikbud.

Parwanto, dkk. 2006. Prosedur Penilaian dengan Pendekatan Praktek. Jakarta: Badan Penelitian dan Pengembangan Departemen Pendidikan Nasional.

Permendiknas. 2005. Peraturan Pemerintah Republik Indonesia Nomor 19 Tahun 2005 tentang Standar Nasional Pendidikan. Jakarta: Permendiknas.

Subagia, W. 2013. Implementasi Pendekatan Ilmiah Dalam Kurikulum 2013 untuk Mewujudkannyatakan Tujuan Pendidikan Nasional. Seminar Nasional FMIPA UNDIKSHA III. 
Sudijono, Anas. 2009. Pengantar Statistik Pendidikan. Jakarta: Puspa Swara.

Wardhani, I.S. 2013. Kurikulum 2013 (Bukan) Pepesan Kosong. (online) www.kompas.com, diakses 20 November 2016.

Wikanengsih, dkk. 2015. “Analisis Rencana Pelaksanaan Pembelajaran (RPP) Mata Pelajaran Bahasa Indonesia (Studi Kasus Terhadap RPP yang Ditulis Guru Bahasa Indonesia di Kota Cimahi)”. Jurnal Ilmiah UPT P2M STKIP Siliwangi. Volume 2, Nomor 1.

Analisis Rencana Pelaksanaan Pembelajaran (RPP) Mata Pelajaran Bahasa Indonesia (Studi Kasus Terhadap RPP yang Ditulis Guru Bahasa Indonesia di Kota Cimahi) 